\title{
Relationship Between Nutritional Status and Students' Physical Condition
}

\author{
Nirwandi $^{1 *}$, Sefri Hardiansyah ${ }^{1}$ \\ ${ }^{1}$ Faculty of Sports Science, Universitas Negeri Padang, Indonesia

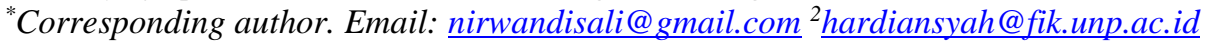

\begin{abstract}
The issue in this research is the low level of FIK UNP students' physical condition. The aim of this research to determine the relationship between nutritional status and students' physical condition. This is a correlational research design involving 17 students of FIK UNP. Nutritional status data were obtained by measuring the Body Mass Index (BMI), and students' physical condition data were obtained through test in several aspects including speed, strength, explosive power and endurance. Data were analyzed using Pearson's product-moment correlation. The results showed that the average of students' nutritional status was at 19.81 with normal classification, while the average of students' physical condition was 56.01 with good classification. Based on the statistical analysis, it was obtained that $t_{\text {observe }} 1.79>t_{\text {table }} 1.753$. Therefore, it can be concluded that there is a significant relationship between nutritional status and FIK UNP students' physical condition.
\end{abstract}

\section{Keywords: Nutritional status, physical condition, student}

\section{INTRODUCTION}

Faculty of Sport Science Faculty organizes an education in the field of sports in which the course is largely practical subjects. In undergoing the activity as a student at the Faculty of Sport Sciences students are required to have excellent physical condition because the students will be busy with a variety of activities ranging from lectures to activities outside the lecture course, consuming energy.

However, from the observations made by the author, is often seen student experience fatigue when the lecture started, and the number of students who are not eager to take the classes, especially the course of practice, this will certainly be inhibit student of activities that should be followed every day. The number of students still experience significant fatigue at the time of a new lecture and low morale likely caused by poor physical condition which is owned by the student because the physical condition of a component that can affect all human activities. Peak physical condition can make a person can carry out all activities to the maximum without experiencing significant fatigue, and can improve the spirit within themselves. Aside from the physical condition factor, the other thing that is likely to affect the students in activities and affect the physical condition itself is a factor of the nutritional status of every student. Nutritional status is a nutritional state that reflects the nutritional intake of a person. The nutritional status can affect the state of the human body, if the nutritional status is good, it will cause physical condition will be better because of insufficient supply of energy needed by the body to support all activities of daily living. Therefore, researchers interested in conducting research on the relationship between nutritional status and the ability of the physical condition of the results of this study are expected to provide an overview of the state of nutritional status and physical condition of the students and can provide solutions to the problems faced by some students of the Faculty of Sport Sciences, State University of Padang

Nutritional Status

"Nutritional status is the level of a person's health is influenced by food eaten that their physical impact can be measured anthropometry" [1]. Furthermore Syafrizar (2009: 4) says nutritional status is "state of the body as a result consumption, absorption and utilization of food in the body". From the above opinion, it can be said that nutritional status is a state body that is affected by the consumption of food. The nutritional status is important for everyone's business because of the advantages and disadvantages of each nutrient can cause many disturbances of health. There are some advantages and disadvantages of the effects of nutrients, namely: "(1) a shortage of carbohydrates cause blood glucose is low, resulting in sluggish and lazy; (2) The resulting protein deficiency and meramus kwashiorkor. Excess protein lead to more severe kidney function and liver disease, as well as a decrease in bone calcium. (3) excessive fat reserves in the body resulting in some heart diseases, kidney, diabetes, high blood pressure, digestive disorders and other diseases [2].

Basedon the above quote can be interpreted that the carbohydrate, protein, calcium and fat is essential for 
health. Lack of carbohydrates will cause the body to become sluggish. Whereas if you eat protein deficiency will cause liver disease, kidney function will be heavy. While the calcium needed for bone growth and bone strengthening, if there is a deficiency of calcium will cause bone growth is inhibited and it will be easier brittle bones. Next need fat. Fat needed by the body as a source of energy, as a source of cell growth, support brain function, helps the absorption of vitamins and support the health of organs. Likewise, if our body fat reserves in excess, will cause obesity will lead to heart disease, kidney, diabetes, high blood pressure, digestive disorders and other degenerative diseases. In addition to carbohydrates, protein and fat or balanced, the body also needs vitamin, for example: Vitamin A serves to help the vision, help growth, maintain healthy skin, maintaining the respiratory system and protects the body from infection. Vitamin B 1 serves to maintain the health of the mucous membranes, maintain the nervous system, muscles and heart. Vitamin D functions for growth, amplification and maintenance of bones with calcium absorption to help the formation of strong bones and teeth, maintaining healthy blood, muscles and nerves. Deficiency or excess of vitamins can cause health problems body.

The nutritional status is very dependent on the eating habits of everyday life, because nutrition is sufficient if not accompanied by a good diet, especially eating schedule will negatively impact the body, therefore it is important for students of the faculty of Sport Science to pay attention to nutrition nutrients from consumed food and eating well arranged so that nutrition can be met so as to support the daily activities as a student. Someone who experienced nutritional deficiencies.

\section{Physical Condition}

"The physical condition of the sport is all physical abilities which determine achievement whose realization is done through personal ability" [4]. "The physical condition is one of the preconditions that are necessary in any efforts to improve the achievement of an athlete, even said to be the foundation of the starting point of a prefix sporting achievement" [5]. Meanwhile, general physical condition can be interpreted by a state or physical ability [3]. From the opinions above, it can be understood that the physical condition is the ability of the body. The physical condition comprises:

\section{Speed}

"The speed is the ability to move with the fastest speed possibility" [8]. While is the speed of the body's ability to direct all of its systems in the fight against the load, distance and time produce mechanical work [3]. Of the two opinions, it can be said that the speed is the body's ability to travel long distances in a short time.

\section{Strength}

The strength of muscle contraction force is achieved in a maximum effort [8]. According in "power describes the ability of muscles to contract maximally yangh generated by a muscle or group of muscles" [9]. So power is the maximum capacity when the muscles contract.

\section{Explosive Power}

Explosive power is a blend or a combination of strength and speed, and "the explosive power is the ability of muscles to overcome the resistance of the load at high speed in a movement intact' [2]. So explosive power is the ability of muscles to be able to move strongly and quickly.

\section{Endurance}

Endurance is the ability to overcome fatigue and psychological perform physical labor for a long time [3]. According endurance mean length of a person to perform physical activities without experiencing significant fatigue [2]. So we can say that to endurance is the body's ability to cope with the fatigue when doing physical activity.

The physical condition of a human needs to be able to meet all their daily activities, especially sport science faculty students who have a physical activity so much that it takes peak physical condition for all activities that followed can be accomplished smoothly.

\section{METHOD}

This type of research is a correlation study that looked at the relationship of two or more groups of concern in this study is the relationship between nutritional status (variable $\mathrm{X}$ ) with the ability of the physical condition (Y). The samples in this study were students of the Sport Science Faculty, of Sport amounting to 17 people.

\section{RESULTS}

\section{Nutritional Status}

Based on measurements of nutritional status has been conducted on a sample by using Body Mass Index (BMI), then gained an average of 19.81, median 20:05, 20:20 mode, standard deviation 1:54, 22:23 highest score and lowest score 15.63. for more details of the nutritional status of the measurement results can be seen in the table 1:

Table 1: Nutritional status

\begin{tabular}{|c|c|c|c|}
\hline $\begin{array}{c}\text { IMT } \\
\mathrm{kg} /(\mathrm{cm} / 100)^{2}\end{array}$ & $\begin{array}{c}\text { Frequenc } \\
\mathrm{y} \\
\text { Absolute }\end{array}$ & $\begin{array}{c}\text { Frequenc } \\
\mathrm{y} \\
\text { Relative } \\
(\%)\end{array}$ & $\begin{array}{c}\text { Classificatio } \\
\mathrm{n}\end{array}$ \\
\hline$<17.0$ & 1 & 5.88 & $\begin{array}{c}\text { Underweight } \\
\text { weight level }\end{array}$ \\
\hline $17.0-18.5$ & 1 & 5.88 & $\begin{array}{c}\text { Underweight } \\
\text { light level }\end{array}$ \\
\hline $18.5-25.0$ & 15 & 88.24 & Normal \\
\hline $25.0-27.0$ & 0 & 0.00 & $\begin{array}{c}\text { Mild } \\
\text { overweight }\end{array}$ \\
\hline$>27$ & 0 & 0.00 & $\begin{array}{c}\text { Overweight } \\
\text { weightlevels }\end{array}$ \\
\hline Total & 17 & 100 & \\
\hline
\end{tabular}


From table 1 above it can be seen that the first students $(5.88 \%)$ had the nutritional status of score $<17.0$ with the classification of underweight weight level, 1 person students $(5.88 \%)$ has nutritional status at the interval 17.0 18.5 by category underweight light level, and 15 students $(88.24 \%)$ had a normal nutritional status categories and no student who has the nutritional status of overweight light level overweight and weight levels. Thus it can be said that most of the students of the Faculty of Sport Sciences sampled in this study had nutritional status on the score of 18.5-25 with normal categories and a percentage of $88.24 \%$. the data is then presented into diagram 1 .

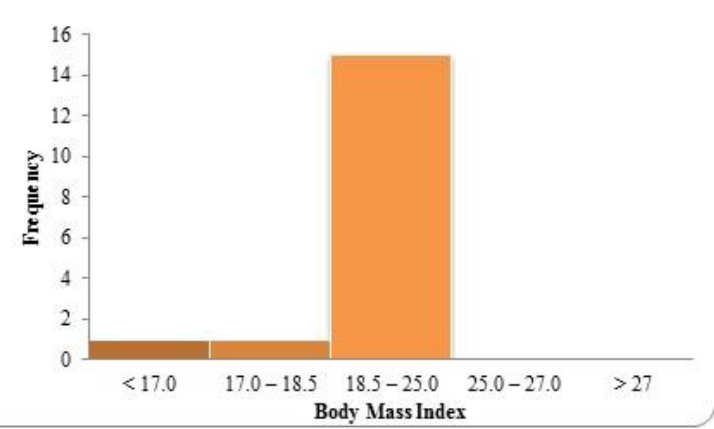

Figure 1: Nutritional Status

\section{Physical Condition}

Based on measurements of the physical condition that has been done on samples obtained an average of 56.01, 58.39 median, standard deviation of 6:51, the highest score of 64.58 and the lowest score 43.20. for more details of the physical condition of the measurement results can be seen in table 2 :

Table 1: Physical condition

\begin{tabular}{|c|c|c|c|}
\hline $\begin{array}{c}\text { Interval } \\
\text { Class }\end{array}$ & $\begin{array}{c}\text { Frequency } \\
\text { Absolute }\end{array}$ & $\begin{array}{c}\text { Frequency } \\
\text { Relative } \\
(\%)\end{array}$ & Classification \\
\hline$>65.78$ & 0 & 0.00 & Very Good \\
\hline $\begin{array}{c}59.27- \\
65.78\end{array}$ & 6 & 35.29 & Good \\
\hline $\begin{array}{c}52.76- \\
59.26\end{array}$ & 6 & 35.29 & Average \\
\hline $\begin{array}{c}46.24- \\
52.75\end{array}$ & 3 & 17.65 & Poor \\
\hline$<46.24$ & 2 & 11.76 & Very Poor \\
\hline Total & 17 & 100 & \\
\hline
\end{tabular}

Than 2 above tabel it can be seen that no student $(0.00 \%)$ had the ability physical condition scores $<65.78$ with very good category, at 59.27-65.78 score as many as 6 people $(35.29 \%)$ in good categories, 6 students $(35.29 \%)$ had the physical conditions at the interval 52.76-59.26 with average category, and 3 students $(17.65 \%)$ had a physical condition in the poor category and 2 students (11.76) which has a physical condition at very poor category. Thus it can be said that most of the students of the Faculty of Sport Sciences sampled in this study has the capability of physical conditions in both categories and are with a percentage of $35.29 \%$. these results can also be seen in the diagram 2 .

\section{Hypothesis Analysis}

Hypothesis in this research is a significant relationship between nutritional status and physical condition of the ability of students of the Faculty of Sport Sciences. Hypotheses were tested using correlation test and continued with $t$ significance test at significance level $\alpha$ of $0.05 \%$. From the analysis of the data obtained byt $t_{\text {the }}$ (1.79)> $\mathrm{t}_{\text {table }}(1,753)$, and thus $\mathrm{H}_{0}$ is rejected and $\mathrm{Ha}$ accepted meaning this hypothesis empirically accepted as true.

Based on the research that has been done it can be seen that the hypothesis that there is a significant relationship between nutritional status and the ability of the physical condition can be accepted as true empirically. This proves that the relationship between physical condition and nutritional status directly proportional, if the nutritional status that are owned by either the student will come good physical condition, but on the contrary if the nutritional status of which is owned by the student is low, then the state will participate fisikpun low. Thus, one of the businesses that can be done to improve the physical condition of students is to improve the nutritional status of students themselves.

For improving the nutritional status it must first know the factors that could affect the nutritional status. The factors affecting the nutritional status of a person, namely: "1) Food products, 2) distribution of food or food, 3) acceptability (acceptance), 4) the prejudice in certain foodstuffs, 5) prohibition on certain foods, 6) preference for certain foods, 7) economic constraints, 8) eating habits, 9) appetite, 10) sanitation of food (preparation, presentation, storage) and 11) knowledge of nutrition" [6]. Furthermore "Factors affecting the nutritional status, among others, (a) the availability of food; (b) knowledge of nutrition; (c) eating habits; (d) the level of income" [7]. Of the two opinions are the things to consider in improving the nutritional status is by paying attention to food availability. Food security is a guarantee of the availability of raw materials needs to be consumed in order to avoid gaps or lack of eating that has enough nutritional value. Next is to provide education or knowledge to students to pay attention to the nutritional value of food consumed every day and observe the variety of foods consumed, the next is adjust your diet, diet is crucial once the benefits of nutritional consumed, if wrong in making dietary adjustments the nutrients produced by the food consumed will not be helpful to the maximum can even cause harm such as the accumulation of fat, diseases of the stomach as well as a variety of other adverse effects. Therefore, in order that the nutrients produced by the food is consumed can provide the maximum benefit would require setting a good diet. 


\section{CONCLUSION}

Based on the research that has been done it can be concluded in this study is a significant relationship between nutritional status and physical condition of the ability of Sport Science Faculty student Padang State University.

Based on the conclusions set forth above, the authors give advice to students in order to pay attention to the nutritional value of food dikonsumsi and regulate eating well.

\section{REFERENCES}

[1] Suhardjo, "Perencanaan Pangan dan Gizi," Jakarta; PT Bumi Aksara, pp, 89-110. 1996.

[2] Hardiansyah Sefri, "The Influence of Circuit Training Method on The Enhancement of Physical Fitness of Sports Education Department Students," Proceedings The $1^{\text {st; }}$ Yogyakarta international seminar on health, physical education, and sports science. 2017.

[3] Syafruddin, Perangkat Pembelajaran Ilmu Melatih Dasar," Padang; FIK UNP, pp, 56-60. 2016.

[4] Pasurnay Paulus Levinus, "Latihan Fisik Olahraga. Pusat Pendidikan," KONI Pusat; Yogyakarta. 2001.

[5] Sajoto, Muchammad, "Pembinaan Kondisi Fisik dan Olahraga,” Jakarta; Depdikbud. 1988.

[6] Krisno A, "Dasar-Dasar Ilmu Gizi." Malang; UMM PRESS. 2004.

[7] Gusril, "Perkembangan Motorik Pada Masa Anak-Anak." Dirjen Olahraga Departemen Pendidikan Nasional. 2004.

[8] Ismaryati, "Tes dan Pengukuran Olahraga," Surakarta: UNS Press. 2008.

[9] Abidin, Akros, "Penuntun Bola Basket Kembar," Jakarta; PT. Raja Grafindo Persada.1999. 